\title{
Daya Dukung dan Prioritas Wilayah Pengembangan Ternak Sapi Potong di Kota Tangerang Selatan
}

\author{
Carrying Capacity and Priority Region for Development of Beef Cattle Production in South Tangerang \\ PS. Yuniar ${ }^{1)}$, AM Fuah $^{2)}$ \& Widiatmaka ${ }^{3)}$ \\ 1)Program Studi Ilmu Perencanaan Wilayah, IPB. Jl. Meranti Kampus IPB Dramaga \\ ${ }^{2)}$ Departemen Ilmu Produksi dan Teknologi Peternakan Fakultas Peternakan IPB \\ Jl. Agatis Kampus IPB Darmaga Bogor \\ ${ }^{3}$ Departemen Ilmu Tanah dan Sumberdaya Lahan Fakultas Pertanian IPB \\ Jl. Meranti Kampus IPB Darmaga, Bogor
}

\begin{abstract}
The objective of this studi was to determine development strategy of beef cattle based on the physical characteristics of Tangerang Selatan city. The primary data were obtained from interviews with stakeholders. Secondary data were obtained from relevant agencies and literature review. The analytical method that was used in this study was a combination of Hierarchy Analysis Procedure (AHP) and Technique for Order Preference by Similarity to Ideal Solution (TOPSIS). The results showed that Tangerang Selatan city has enough carrying capacity for beef cattle production based on land characteristics, suitabilities and forage carrying capacity. The priority development of beef cattle was determined based on potential and developmental direction of Tangerang Selatan city which are Pondok Aren, Ciputat, Serpong Utara and Ciputat, respectively.
\end{abstract}

Keywords: AHP TOPSIS , carrying capacity.

\section{PENDAHULUAN}

Rencana penyebaran dan pengembangan ternak di suatu wilayah harus melalui analisis potensi yang dimiliki wilayah tersebut berkaitan dengan ketersediaan sumber daya lahan dan daya dukung, komoditas yang akan dikembangkan serta sarana dan prasarana yang mendukung. Menurut Mukson et al. (2005), aspek yang perlu dipertimbangkan dalam program pengembangan meliputi ketersediaan pakan, Produk Domestik Regional Bruto (PDRB), sarana dan prasarana pendukung dan kelembagaan. Penyebaran dan pengembangan ternak di daerah bertujuan untuk membentuk kawasan peternakan, keseimbangan pembangunan antar wilayah, optimalisasi sumberdaya untuk meningkatkan pendapatan peternak, populasi dan produksi, dalam rangka pemberdayaan masyarakat peternak. Visi pembangunan peternakan telah ditetapkan yaitu terwujudnya masyarakat yang sehat dan produktif serta kreatif melalui pembangunan peternakan tangguh berbasis sumberdaya lokal. Untuk mewujudkan visi tersebut grand strategy yang ditempuh adalah melalui pembangunan secara menyeluruh seluruh sistem dan usaha agribisinis peternakan mulai dari subsistem hulu, subsistem budidaya, subsistem hilir dan subsistem jasa-jasa pendukung. Dengan dikeluarkannya UU No. 22 tahun 1999 dan PP No. 25 tahun 2000 tentang Otonomi Daerah, peran pemerintah provinsi, kabupaten dan kota semakin penting dalam mewujudkan cita-cita pembangunan agribisnis peternakan di Indonesia (Makka 2004).
Pertanian kota secara umum digambarkan sebagai kegiatan budidaya, pengolahan dan distribusi tanaman pangan dan non pangan, pohon dan peternakan yang secara langsung untuk memenuhi pasar perkotaan baik di dalam maupun di sekitar wilayah perkotaan (pinggiran perkotaan) (Mougeot 2006). Menurut Specht et al. (2014) pertanian perkotaan merupakan suatu sistem pertanian yang inovatif yang mengimplementasikan sustainable farming system untuk produksi pangan berkelanjutan. Pertanian perkotaan yang di dalamnya termasuk peternakan yang berada di perkotaan dan pinggiran kota memberikan keuntungan ekologis dengan cara mengurangi limbah, meningkatkan biodiversitas dan kualitas udara dan mengurangi pengaruh lingkungan terkait dengan transportasi dan penyimpanan ternak dan produk hasil ternak (Orisini et al. 2013). Menurut Diogo et al. (2013), pertanian perkotaan dan pinggiran perkotaan dapat meningkatkan efisiensi penggunaan nutrisi mikro dan makro di sektor peternakan dengan cara peningkatan suplai pakan dan menegemen limbah yang tepat sehingga dapat meningkatkan produksi dan mengurangi emisi nitrogen karena limbah dapat langsung dimanfaatkan sebagai pupuk untuk pakan. Beberapa tipe pertanian perkotaan yang diterapkan di Afrika barat yaitu peternakan tunggal, peternakan dan perkebunan, peternakan dan pertanian (sawah) dan peternakan yang dikombinasikan dengan perkebunan dan pertanian (Diogo et al. 2013)

Konsep tersebut sudah mulai berkembang di masyarakat daerah perkotaan untuk membantu ketersediaan 
bahan pangan khususnya produk peternakan. Masyarakat memiliki kesempatan untuk dapat berperan serta mewujudkan kecukupan pangan yang berasal dari produk pertanian dan peternakan terutama aktivitas atau usaha di bidang penyediaan sarana prasarana, produksi, perdagangan dan distribusi produk peternakan termasuk logistik peternakan yang memegang peranan penting dalam sistem produksi peternakan hulu-hilir.

Kota Tangerang Selatan merupakan pemekaran dari dari Kabupaten Tangerang. dengan luas relatif kecil yaitu $164,54 \mathrm{~km}^{2}$ dan jumlah penduduk yang besar 2.834.376 Jiwa (Dinas Pemerintah Kota Tangerang 2015). Menurut Hardjowigeno dan Widiatmaka (2011), kesesuaian lahan penting untuk menjamin tingkat penggunaannya secara optimal dan lestari, terutama lahan untuk ternak sapi potong sangat penting untuk keberhasilan peningkatan produksi dan produktivitas ternak. Beberapa hasil studi tentang aspek lingkungan menunjukkan bahwa ternak yang berada di wilayah dengan kondisi lingkungan fisik yang sesuai dan pakan yang cukup memperlihatkan pertumbuhan ternak yang baik yang ditandai oleh pertambahan bobot badan optimal. Menurut Silanikove (2000), lingkungan yang cocok sangat baik untuk mendukung pertumbuhan ternak. Penelitian ini bertujuan untuk menganalisis potensi wilayah berdasarkan karakteristik fisik dalam rangka pengembangan peternakan sapi potong perkotaan di Kota Tangerang Selatan.

\section{MATERI DAN METODE}

Data yang dikumpulkan terdiri dari data primer dan data sekunder. Data primer diperoleh melalui wawancara terhadap 12 responden sebagai aktor yang berpengalaman dalam berternak dari kelompok peternak yang ada di Kota Tangerang Selatan dengan menggunakan daftar perntanyaan terstruktur. Data sekunder berasal dari studi literatur, peta administrasi Kota Tangerang Selatan, peta tanah semi detail daerah tangerang dan sekitarnya dan data populasi ternak sapi potong Kota Tangerang Selatan tahun 2012 dan 2014.

Strategi pengembangan ternak sapi potong menggunakan metode AHP (Analytical Hierarchy Process) dan TOPSIS (Technique for Order Preference by Similarity to Ideal Solution). Analisis AHP-TOPSIS, LQ (Location Quotient) dan SSA digunakan untuk menganalisis kesesuaian lingkungan ekologis ternak, ketersediaan lahan dan daya dukung hijauan makanan ternak. Proses pemilihan dan arahan prioritas pengembangan ternak sapi potong ditentukan melalui: 1) menentukan tujuan dan arahan prioritas pengembangan ternak; 2) penentuan kriteria; 3) penentuan solusi alternatif. Analisis TOPSIS dilakukan dengan menggunakan software Sanna 7 dilanjutkan dengan pemilihan alternatif kecamatan prioritas pengembangan dilakukan menggunakan pendekatan MCDM (Multicriteria Decision Making). Menurut Kusumadewi et al. (2006) metode AHPTOPSIS sangat berguna dalam pengambilan keputusan multi atribut/multi kriteria dan mampu membantu para pengambil keputusan dalam memecahkan masalah, mampu memberi alternatif secara logis dan merepresentasikan pilihan-pilihan secara rasional. Proses pembobotan kriteria menggunakan metode AHP bertujuan untuk menghindari subyektifitas penilaian pada kriteria-kriteria yang dijadikan sebagai input. Urutan prioritas alternatif wilayah merupakan indikasi kedekatan relatif dari alternatif wilayah terhadap solusi ideal positif sehingga altenatif dengan nilai tertinggi merupakan solusi yang terbaik untuk pengembangan sapi potong (Yuniar et al. 2015)

\section{HASIL DAN PEMBAHASAN}

Pola pemusatan ternak diperoleh dengan Analisis Location Quotient (LQ) dilakukan untuk mengetahui apakah usaha peternakan sapi potong merupakan sektor basis atau non basis pada setiap kecamatan. Hasil analisis LQ juga menggambarkan pemusatan nilai kepadatan ekonomi ternak sapi potong dibandingkan dengan total nilai kepadatan ekonomi ternak di Kota Tangerang Selatan. Analisis SSA mampu menggambarkan apakah pemusatan usaha ternak tersebut mengalami tren pertumbuhan positif atau negatif. Menurut Hendayana (2003) untuk komoditas yang berbasis lahan seperti tanaman pangan, hortikultura, dan perkebunan maka perhitungan LQ didasarkan pada lahan pertanian seperti areal tanam maupun areal panen, sedangkan untuk komoditas yang tidak berbasis pada lahan seperti peternakan dasar perhitungan yang digunakan adalah jumlah populasi ternak (ekor). Hasil analisis LQ

Tabel 1 Nilai LQ dan komponen differential shift kepadatan ternak sapi potong Kota Tangerang Selatan

\begin{tabular}{lcc}
\hline Kecamatan & LQ Tahun 2014 & DS Tahun 2011-2014 \\
\hline Pamulang & 1,18 & 1,82 \\
Ciputat & 0,86 & 0,99 \\
Ciputat Timur & 0,00 & $-1,93$ \\
Setu & 1,30 & 0,51 \\
Serpong & 1,09 & 0,15 \\
Serpong Utara & 0,00 & $-1,93$ \\
Pondok Aren & 0,76 & $-0,80$ \\
\hline
\end{tabular}

dan SSA komoditas ternak di Kota Tangerang Selatan disajikan pada Tabel 1.

Berdasarkan nilai LQ dan SSA komoditas ternak dapat dijelaskan bahwa kecamatan basis bagi komoditas ternak sapi potong adalah kecamatan yang memiliki nilai LQ $>1$ dan SSA positif untuk komoditas ternak sapi potong pada kecamatan tersebut, sebaliknya wilayah non basis adalah kecamatan yang memiliki nilai LQ $<1$ dan SSA negatif untuk komoditas ternak sapi potong. Tabel 1 menunjukkan bahwa kecamatan basis dengan trend pertumbuhan positif berada di Kecamatan Pamulang, Setu dan Serpong.

Yuniar et al. (2015) mengatakan bahwa berdasarkan analisis spasial menunjukkan bahwa area seluas 3.174 ha merupakan area yang Sesuai (S) sebagai lingkungan ekologis sapi potong. Secara kebetulan wilayah Kota Tangerang Selatan merupakan satu satuan peta lahan untuk kriteria penilaian sebagai lingkungan ekologis sapi potong, sehingga lahan yang tersedia merupakan lahan yang sesuai untuk lingkungan ekologis sapi potong. Kesesuaian lingkungan ekologis sapi potong yang dianalisis di sini adalah kesesuaian lingkungan ekologis sapi dengan sistem dikandangkan, karena sebagian besar usaha peternakan sapi di Kota Tangerang Selatan adalah 
Tabel 2 Luas kesesuaian lingkungan ekologis ternak sapi potong sistem kandang per kecamatan di Kota Tangerang Selatan

\begin{tabular}{lcccc}
\hline Kecamatan & \multicolumn{3}{c}{ Luas (ha) } & Jumlah \\
\cline { 2 - 4 } & $\mathrm{S}$ & $\mathrm{N}$ & $\mathrm{TD}$ & \\
\hline Ciputat & 428 & - & 1.686 & 2.114 \\
Ciputat Timur & 311 & - & 1.498 & 1.809 \\
Pamulang & 626 & - & 2.247 & 2.873 \\
Pondok Aren & 454 & - & 2.545 & 2.999 \\
Serpong & 594 & - & 2.235 & 2.829 \\
Serpong Utara & 344 & - & 1.892 & 2.236 \\
Setu & 417 & - & 1.266 & 1.683 \\
\hline Jumlah & 3.174 & - & 13.369 & 16.543 \\
\hline Keteran
\end{tabular}

Keterangan: $\mathrm{S}=$ sesuai; $\mathrm{N}=$ tidak sesuai; $\mathrm{TD}=$ tidak dinilai/tidak tersedia.

dengan sistem dikandangkan. Luas kesesuaian lahan lingkungan ekologis sapi potong di Kota Tangerang Selatan pada masing-masing kecamatan terlihat pada Tabel 2.

Kesesuaian lahan hijauan makanan ternak yang dianalisis merupakan gabungan dari kesesuaian lahan untuk pertanian yaitu padi sawah dan ubi jalar serta kesesuaian lahan untuk tanaman rumput gajah, rumput setaria, leguminosa dan rumput alam. Hasil analisis hijauan makanan ternak dari gabungan dari kesesuaian lahan untuk pertanian dan hijauan ditunjukkan pada Tabel 3.

Data pada Tabel 3 menunjukkan bahwa setelah di-overlay seluruh lahan yang tersedia untuk hijauan makanan ternak merupakan lahan yang sesuai seluas 3.882 ha yang tersebar di semua kecamatan. Ketersediaan hijauan makanan ternak diperoleh berdasarkan daya dukung hijauan dan indeks daya dukung. Perhitungan luas, nilai daya dukung, indeks daya dukung, jenis penggunaan lahan, dan pembuatan peta dengan pendekatan SIG, yaitu dengan proses joint tabel basis data dengan tabel data atribut peta digital satuan lahan, dilanjutkan query untuk membuat peta status daya dukung. Basis data awal yang dibutuhkan antara lain kelas kesesuaian lahan masingmasing jenis tanaman yang diperhitungkan.

Luas lahan untuk hijauan makanan ternak digunakan untuk menentukan produksi dari masing-masing jenis tanaman yang ada. Indeks daya dukung hijauan

Tabel 3. Luas lahan hijauan makanan ternak di Kota Tangerang Selatan

\begin{tabular}{lcccc}
\hline \multirow{2}{*}{ Kecamatan } & \multicolumn{4}{c}{ Luas Lahan (ha)* } \\
\cline { 2 - 5 } & $\mathrm{S}$ & $\mathrm{N}$ & $\mathrm{TD}$ & Jumlah \\
\hline Ciputat & 541 & - & 1.576 & 2.117 \\
Ciputat Timur & 329 & - & 1.457 & 1.786 \\
Pamulang & 698 & - & 2.173 & 2.871 \\
Pondok Aren & 719 & - & 2.288 & 3.002 \\
Serpong & 737 & - & 2.102 & 2.839 \\
Serpong Utara & 412 & - & 1.825 & 2.237 \\
Setu & 446 & - & 1,24 & 1.686 \\
\hline Jumlah & 3.882 & - & 12.715 & 16.543 \\
\hline
\end{tabular}

Keterangan : $\mathrm{S}=$ sesuai; $\mathrm{N}=$ tidak sesuai; $\mathrm{TD}=$ tidak dinilai/tidak tersedia. makanan ternak dapat menggambarkan status daya dukung makanan ternak pada masing-masing kecamatan, apakah tergolong aman, rawan, kritis atau sangat kritis. Hal tersebut sesuai dengan Setiawan dan Sudaryono (2014) menjelaskan bahwa ketersediaan pakan, jumlah peternak, kelembapan, temperatur, kepadatan ternak, ketersediaan air termasuk daya dukung lingkungan yang mempengaruhi keberhasilan proses produksi. Menurut Marwan et al. (2014), daya dukung (DD) hijauan makanan ternak berdasarkan bahan kering sebesar 194.442 ST dengan jumlah peningkatan populasi ternak $133.093 \mathrm{ST}$, lebih tinggi dibanding DD di Kota Tangerang Selatan sebesar 18.645,51 ST (Tabel 4).

Arahan pengembangan peternakan sapi potong berdasarkan karakteristik fisik wilayah Kota Tangerang Selatan disusun dengan cara mensintesiskan hasil analisis karakteristik fisik wilayah Kota Tangerang Selatan. Adapun pertimbangan yang digunakan dalam menyusun arahan pengembangan ternak sapi potong dalam penelitian ini terdiri dari tiga kriteria yaitu : (1) nilai LQ tahun 2014 dan SSA tahun 2011-2014 komoditas ternak sapi potong; (2) kesesuaian lingkungan ekologis ternak sapi potong; (3) daya dukung hijauan makanan ternak. Dengan beberapa pertimbangan di atas, maka disusunlah arahan kecamatan prioritas pengembangan dengan ketentuan sebagai berikut:

1. Kecamatan yang tergolong sebagai kecamatan basis bagi peternakan sapi potong yang diindikasikan dengan nilai $\mathrm{LQ}>1$ dan $\operatorname{SSA}(+)$. Kecamatan nonbasis tidak diprioritaskan untuk pengembangan sehingga tidak dijadikan sebagai input dalam analisis TOPSIS.

2. Kecamatan yang memiliki lahan sesuai dan tersedia untuk lingkungan ekologis ternak sapi potong yang terluas. Semakin luas lahan yang sesuai dan tersedia, maka kecamatan tersebut semakin diprioritaskan untuk pengembangan.

3. Kecamatan dengan nilai indeks daya dukung hijauan makanan ternak yang tinggi. Semakin tinggi nilai IDD hijauan makanan ternak di kecamatan tersebut, maka semakin diprioritaskan untuk dikembangkan.

Sebelum dilakukan pemilihan alternatif kecamatan prioritas dengan metode MCDM TOPSIS, maka terlebih dahulu dilakukan pembobotan kriteria dengan menggunakan metode AHP yang bertujuan untuk menghindari subyektifitas penilaian pada kriteria-kriteria yang dijadikan sebagai input dalam metode TOPSIS tersebut. Pembobotan kriteria dengan metode AHP dilakukan dengan wawancara/kuesioner terhadap tiga orang responden yang dianggap ahli/ expert, berpengalaman dan mengerti benar permasalahan yang ada mengenai tingkat kepentingan kriteria dalam bentuk pendapat kualitatif. Hasil wawancara/kuesioner berupa nilai matriks perbandingan berpasangan (pairwise comparison) untuk masing-masing ahli. Nilai perbandingan berpasangan setiap pendapat para ahli/ expert yang terdiri dari 3 orang tersebut disatukan dengan metode rata-rata geometri. Hal ini sebagaimana yang dikemukakan oleh Saaty (1991) yang menyatakan bahwa untuk menggabungkan penilaian individu menjadi sebuah penilaian kelompok yang representatif, semua penilaian harus dikombinasikan menggunakan metode rata-rata geometri (geometric mean). Perhitungan bobot kriteria 
Tabel 4 Indeks daya dukung (IDD) hijauan makanan ternak masing-masing kecamatan

\begin{tabular}{lccccccc}
\hline Kecamatan & $\begin{array}{c}\text { Populasi Sapi } \\
\text { Potong (ST) }\end{array}$ & $\begin{array}{c}\text { Kebutuhan } \\
\text { pakan minimum } \\
\text { (ton BKC/thn/ } \\
\text { ST) }\end{array}$ & $\begin{array}{c}\text { Kebutuhan } \\
\text { pakan ternak } \\
\text { (ton BKC/thn) }\end{array}$ & $\begin{array}{c}\text { Produksi bahan } \\
\text { kering hijauan } \\
\text { (ton BKC) }\end{array}$ & DD (ST) & IDD & Kriteria \\
\hline 1 & 2 & 3 & $4(3 \times 2)$ & 5 & $6(5 / 3)$ & $7(7 / 3)$ & 8 \\
Ciputat & 18 & 1,83 & 32,94 & $4.473,85$ & $2.444,72$ & 135,82 & Aman \\
Ciputat Timur & 1 & 1,83 & 1,83 & $2.453,60$ & $1.340,77$ & $1.340,77$ & Aman \\
Pamulang & 78 & 1,83 & 142,74 & $5.516,35$ & $3.014,40$ & 38,65 & Aman \\
Pondok Aren & 79 & 1,83 & 144,57 & $7.149,27$ & $3.906,70$ & 49,45 & Aman \\
Serpong & 66 & 1,83 & 120,78 & $6.847,19$ & $3.741,63$ & 56,69 & Aman \\
Serpong Utara & 1 & 1,83 & 1,83 & $4.047,36$ & $2.211,67$ & $2.211,67$ & Aman \\
Setu & 105 & 1,83 & 192,15 & $3.633,58$ & $1.985,56$ & 18,91 & Aman \\
\hline Jumlah & 348 & 1,83 & 636,84 & $34.121,28$ & $18.645,51$ & 53,58 & \\
\hline
\end{tabular}

sebagai masukan (input) analisis TOPSIS dilakukan dengan menggunakan software Expert choice 11. Hasil pembobotan masing-masing kriteria maupun nilai CI (consistency index) dapat dilihat pada Tabel 5.

Urutan prioritas pengembangan wilayah berdasarkan komoditas peternakan sapi potong di Kota Tangerang Selatan menurut nilai R.U.V TOPSIS berturutturut sebagai berikut: (1) Kecamatan Serpong (R.U.V 0,95422); (2) Kecamatan Pamulang (R.U.V 0,80677); (3) Kecamatan Setu (R.U.V 0,61415); (4) Kecamatan Pondok Aren (R.U.V 0,44804); (5) Kecamatan Ciputat (R.U.V 0,24797); (6) Kecamatan Serpong Utara (R.U.V 0,19144); dan (7) Kecamatan Ciputat Timur (R.U.V 0,00000). Berdasarkan nilai R.U.V hasil analisis TOPSIS, maka dalam penelitian ini perencanaan pengembangan diprioritaskan pada kecamatan dengan nilai R.U.V yang tinggi, sehingga arahan pengembangan peternakan sapi potong di Kota Tangerang Selatan menurut skala prioritas selengkapnya disajikan pada Tabel 6, sedangkan secara spasial lokasi arahan pengembangan ternak sapi potong di Kota Tangerang Selatan dapat dilihat pada Gambar 1. Menurut Mayulu et al. (2010), peningkatan produksi sapi potong perlu model pengembangan dan kelembagaan kelompok ternak serta dukungan dari pemerintah berupa pelayanan dan pembangunan kawasan berdasarkan kapasitasn daya dukung masing-masing wilayah sehingga mampu memacu perkembangan agroindustri. Upaya pengembangan pertanian di Kota Tangerang Selatan bertujuan meningkatkan kesejahteraan masyarakat melalui berbagai perbaikan fasilitas dan layanan serta melakukan program-program yang berbasis pertanian-peternakan, meningkatkan peran masyarakat dalam pertanian kota,

Tabel 5. Hasil pembobotan kriteria dan nilai Consistency Index (CI) berdasarkan analisis AHP

\begin{tabular}{lcc}
\hline Kriteria & Bobot & $\begin{array}{c}\text { Consistency } \\
\text { Index }\end{array}$ \\
\hline $\begin{array}{l}\text { Nilai LQ dan SSA } \\
\text { Kesesuaian Ekologis Ternak Sapi }\end{array}$ & 0,323 & 0,004 \\
$\begin{array}{l}\text { Potong } \\
\text { Daya Dukung Hijauan Makanan } \\
\text { Ternak }\end{array}$ & 0,437 & \\
\hline Jumlah & 10.000 & \\
\hline
\end{tabular}

program yang dilaksanakan fokus pada komoditas pertanian (Maharisi et al. 2014).

\section{KESIMPULAN}

Berdasarkan hasil yang diperoleh dapat disimpulkan bahwa Kota Tangerang Selatan memiliki daya dukung yang cukup untuk pengembangan ternak berdasarkan karakteristik dan kesesuaian lahan serta ketersediaan hijauan makanan ternak. Prioritas lokasi ditentukan berdasarkan potensi dan arah pengembangan yang didukung oleh sumber daya peternak dan kebijakan pemerintah dalam pengembangan peternakan perkotaan.

\section{DAFTAR PUSTAKA}

Alexandi, M.F., O. Marshafeni. 2013. Penyerapan Tenaga Kerja pada Sektor Pertanian dan Sektor Jasa Pasca kebijakan Upah Minimum di Provinsi Banten (Periode Tahun 2001-2011). Jurnal Manajemen \& Agribisnis. $10(2): 71-80$.

[BPS] Badan Pusat Statistik Kota Tangerang Selatan. 2014. Kota Tangerang Selatan Dalam Angka 2014. Tangerang Selatan (ID): BPS Kota Tangerang Selatan.

[DPKP] Dinas Pertanian dan Ketahanan Pangan Kota Tangerang Selatan. 2014a. Laporan Hasil Forum SKPD 2011-2014. Tangerang Selatan.

[DPKP] Dinas Pertanian dan Ketahanan Pangan Kota Tangerang Selatan. 2014b. Profil Bidang Peternakan Kota Tangerang Selatan. Tangerang Selatan.

Diogo, R.V.C., S. Eva, A. Buerkert, C.R. Mariana, T. Mark, W. Van. 2013. Increasing nutrient use efficiency through improved feeding and manure management in urban and peri-urban livestock units of a West African city: A scenario analysis. Agricultural system. 114:6472

Hardjowigeno, S., \& Widiatmaka. 2011. Evaluasi Kesesuaian Lahan dan Perencanaan Tataguna Tanah. Edisi 1. Yogyakarta (ID) : Gadjah Mada University Press.

Hendayana, R. 2003. Aplikasi metode location quotient (LQ) dalam penentuan komoditas unggulan nasional. Informatika Pertanian. 12: 1-21 


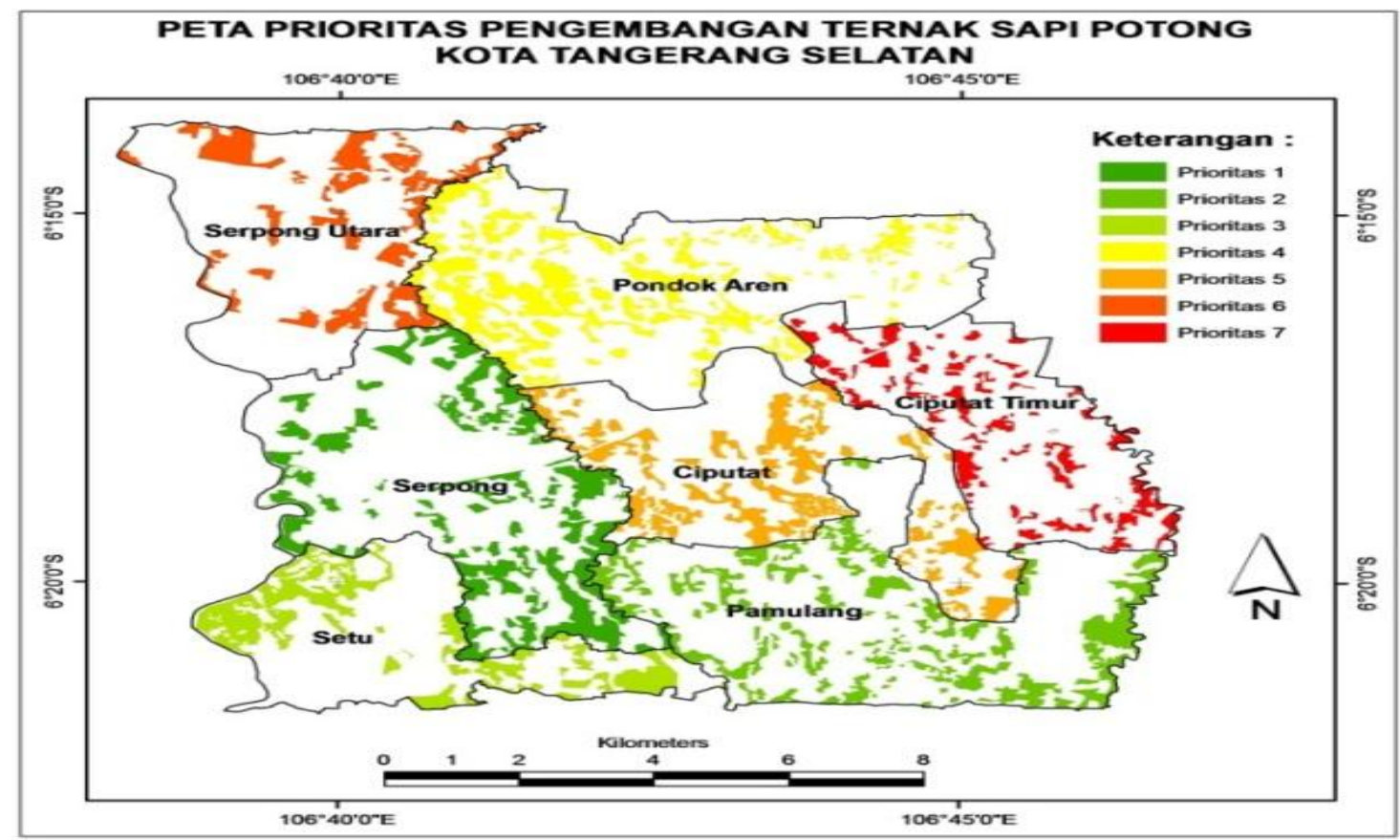

Gambar 1 Peta prioritas arahan pengembangan ternak sapi potong di Kota Tangerang Selatan

Tabel 6. Prioritas pengembangan peternakan sapi potong di Kota Tangerang Selatan

\begin{tabular}{lcccc}
\hline Kecamatan & Wilayah basis/ nonbasis & Kesesuaian ekologis ternak (ha) & Daya Dukung HMT (ST) & Arahan pengembangan \\
\hline Ciputat & Nonbasis & 428 & $2.444,72$ & Prioritas 5 \\
Ciputat Timur & Nonbasis & 311 & $1.340,77$ & Prioritas 7 \\
Pamulang & Basis & 626 & $3.014,40$ & Prioritas 2 \\
Pondok Aren & Nonbasis & 454 & $3.906,70$ & Prioritas 4 \\
Serpong & Basis & 594 & $3.741,63$ & Prioritas 1 \\
Serpong Utara & Nonbasis & 344 & $2.211,67$ & Prioritas 6 \\
Setu & Basis & 417 & $1.985,56$ & Prioritas 3 \\
\hline Jumlah & & 3.174 & $18.645,51$ & \\
\hline
\end{tabular}

Kusumadewi S. Hartati, S. Harjoko, Agus, Wardoyo, dan Retyanto. 2006. Multi Attribute Decision Making. Yogyakarta (ID): Gadjah Mada University Press.

Maharisi S., Machfud, A. Maulana. 2014. Manajemen Strategi Pengembangan Pertanian Kota (Urban Agriculture) di Kota Tangerang Selatan. Jurnal Aplikasi Manajemen. 12 (3) : 351-361

Makka D. 2004. Prospek Pengembangan Sistem Integrasi Peternakan Yang Berdaya Saing. Prosiding Seminar Nasional Sistem Integrasi Tanaman-Ternak : 18-32.

Marwan, M. Mukhtiar, S. Bahri. 2014. Potensi dan daya dukung hijauan makanan ternak sapi potong di Kabupaten gorontalo. KMFIIP. 2 (2):1-16.

Mayulu H., Sunarso, I. Sutrisno, Sumarsono . 2010. Kebijakan pengembangan peternakan sapi potong di Indonesia. JPPP. 29 (1): 35-41

Mugeot LJA. 2006. Growing Better Cities: Urban Agriculture for Sustainable Development. Canada : International Development Research Centre.

Mukson, E. Prasetyo, B.M. Setiawan, H. Setiyawan. 2005. Analisis Faktor-Faktor Yang Mempengaruhi Pengembangan Peternakan Di Jawa Tengah. Journal of Animal Agricultural Socio-economics. 1 (1).
Orisini F., K. Remi, N.W. Remi, G. Giorgio. 2013. Urban agriculture in the developing world: a review. Agron. Sustain. Dev. 1-36. DOI 10.1007/s13593-013-0143-z

Setiawan A., \& L. Sudaryono. 2014. Kajian Daya Dukung Lingkungan Untuk Peternakan Sapi Potong di Kecamatan Kerek Kabupaten Tuban. Jurnal mahasiswa teknologi. 144-155.

Silanikove N. 2000. Effects of Heat Stress on the Welfare of Extensively Managed Domestic Ruminant. Livestock Production Science. $67: 1-18$

Specht K., S. Rosemarie, H. Ina , B.F. Ulf, S. Magdalena, W. Armin, T. Susanne, H. Dietrich, W. Heike, D. Axel. 2014. Urban agriculture of the future: an overview of sustainability aspects of food production in and on buildings. Agric Hum Values. 1-19. DOI 10.1007/ s10460-013-9448-4

Yuniar PS., Widiatmaka, A.M. Fuah. 2015. Analisis Potensi Pengembangan Peternakan Sapi Potong di Kota Tangerang Selatan (Analysis of the Potential Beef Cattle Development in South Tangerang). Jurnal Ilmu Produksi dan Teknologi Hasil Peternakan. 03 (2): 106112 